\title{
Education Is Never For Its Own Sake, It's Much More Important Than That
}

\author{
Patrick Ainley, School of Education, University of Greenwich
}

Cambridge University lecturer Stefan Collini's book last year asked What Are Universities For? Its answer that 'education is for its own sake' struck a chord with many academics because it chimed with a widely held notion of academic freedom. This supposedly allows $\mathrm{HE}$ teachers - unlike school and FE teachers - to set and examine their own courses linked to their personal research interests. Very few academics actually exercise this degree of freedom and Collini's special pleading for them is unlikely to win widespread public support.

More importantly, Collini divides 'higher' from the rest of education by reinforcing the alleged superiority of research (knowledge production) over teaching (knowledge reproduction). This misconceives the nature of teaching by supposing that it merely reproduces what is already known. However, all teachers know that in representing an old subject - even without the scholarship necessary to keep up to date with it - they have to reinterpret what they know both for themselves in new circumstances and for new generations of students for whom that knowledge is necessarily new. Knowledge and skills embedded in culture are thus not handed uncritically down the generations but are developed in teaching, scholarship and research.

Nor is research 'for its own sake', despite repeated government demands for its restriction to national economic 'impact' (in contrast to the REF, incidentally, which recognizes international excellence). As UNESCO's 1997 Resolution on Higher Education states: 'higher education is directed to human development and to the progress of society'. This is a much wider purpose than 'blue skies'/'curiosity driven', 'research for its own sake' which supposedly drives the scientific model of research. (For a corrective insight into how scientists actually work, see Polanyi 1958.)

Both research and teaching supposedly for their own sakes ignore the role of education in critically learning from the past so that society can change its behaviour in the future. Just because education as a whole is currently reneging on this responsibility does not invalidate the claim that it has this wider potential.

'Human development and the progress of society' puts knowledge at the heart of the system, not students - as both Collini and the Coalition government's White Paper say they should be. Anyway, in the fee-driven system that higher education is becoming, most 'consumers' (if not customers!) of learning are not paying for knowledge for its own sake, even if they are often advised to study a subject they are interested in (otherwise they won't stick it out!). Instead, students are willing to become heavily indebted for the chance of employment in the dwindling band of occupations that are not automated, downsized and contracted out but are reasonably secure and rewarding. This is what promises of 'employability' amount to as an alternative to 'education for its own sake'.

Both responses are equally illusory and contribute to the simulacrum of learning that it is now the main danger that commodified education becomes. For we are in trouble if we convince ourselves and our students that what we are doing is education for its own sake, when they have more invested in promises of future employment that both we and they know are often illusory. At best a degree affords only a slight advantage in the jobs queue over those who do not have a degree and education becomes increasingly meaningless and alienating for both students and teachers. Far from being 'for its own sake', it is then an exercise to be undertaken with as little effort by students and maximum direction by staff as possible. 
This is the case whether students are drilling for the tests of levels of literacy required for entry to HE or cramming for regurgitation in academic graduation. These qualifications do not attest to any skilful knowledge but function mainly as proxies for more or less expensively acquired cultural capital. Nor is 'skill' involved in completing competence-based assessments that reduce learning to what Dierdre McArdle-Clinton (2008) calls Capsule Education, broken down into bits to be easily digested.

Paradoxically, new information technology can worsen both these tendencies at either end of the widening academic hierarchy and the e-alternative of 'on demand' teaching and assessment only encourages students who don't, won't or can't read.

Stefan Collini's assertion of 'research and education for their own sakes' against 'research for national economic impact' and 'education for employability' only reinforces the dominance of elite academic HE. Within that elite he further reinforces the dominance of a misconceived model of 'scientific' research over a narrow notion of teaching as transmission for consumption by uncritically fee-paying student-customers.

\section{References}

BIS, (Department of Business, Innovation and Skills) (2011) Higher education: students at the heart of the system, London: BIS.

Collini, S. (2012) What Are Universities For? Harmondsworth: Penguin.

McArdle-Clinton, D. (2008) The Consumer Experience of Higher Education, The Rise of Capsule Education, London: Continuum.

Polanyi, M. (1958) Personal Knowledge, Towards a Post-Critical Philosophy, London: Routledge.

UNESCO (1997) Resolution adopted on the report of Commission II at the 26th plenary meeting, Paris: UNESCO.

\section{Author biography}

Patrick Ainley is professor of Training and Education at the University of Greenwich School of Education and Training (as was). His latest books are: Lost Generation? New strategies for youth and education, Continuum: 2010 and a forthcoming e-book The Great Reversal, Young people, learning and employment in a declining economy. Patrick blogs at http://radicaled.wordpress.com/ 